\title{
Plant Silicon and Phytolith Research and the Earth-Life Superdiscipline
}

\author{
Ofir Katz* \\ Dead Sea and Arava Science Center, Tamar Regional Council, Israel
}

Keywords: plants, silicon, phytolith, earth system, superdiscipline

\section{DISCIPLINARY ORIGINS OF PLANT SILICON AND PHYTOLITH RESEARCH}

Plant silicon and phytolith research stands as a good example for how a single phenomenon or theme is studied by scholars from multiple disciplines, and for how knowledge flows among disciplines. At its very core and origins, plant silicon and phytolith research lies in traditional botany, since it studies the occurrence and role of silicon and phytoliths within plants and among plant groups (e.g., Hodson et al., 2005; Katz, 2014, 2015; Strömberg et al., 2016) and can be potentially used to improve taxonomy and systematics by providing more characters to be included in analyses (e.g., Prychid et al., 2004; Katz, 2014, 2018a). Nevertheless, plant physiologists study the mechanisms of silicon uptake, transport and accumulation within plants (e.g., Peleg et al., 2010; Mitani-Ueno et al., 2014; Ma and Yamaji, 2015; Kumar et al., 2017), chemists study the mechanisms of its deposition (e.g., Currie and Perry, 2007; Patwardhan et al., 2012), ecophysiologists identify silicon's and phytoliths' functions within plant tissues (e.g., Fauteux et al., 2005; Liang et al., 2007; Epstein, 2009; Guntzer et al., 2012; Cooke and Leishman, 2016; Coskun et al., 2016) and ecologists study how silicon and phytoliths interact with herbivores (e.g., Massey and Hartley, 2006; Katz et al., 2014; Hartley, 2015; Frew et al., 2016) and shape plant communities (e.g., Jacobs et al., 2013; Schoelynck et al., 2014; Cooke et al., 2016), ecosystems (e.g., Cooke and Leishman, 2011; Cooke et al., 2016; Schoelynck and Struyf, 2016), and even biomes and the entire ecosphere (e.g., Carey and Fulweiler, 2012, 2016; Song et al., 2012, 2017; Katz, 2018b).

Within Earth sciences, biogeochemists study the physics and chemistry of plant silicon and phytoliths, including their dissolution (e.g., Fraysse et al., 2009; Cabanes and Shahack-Gross, 2015) and chemical and isotopic composition (e.g., Hodson et al., 2008; Kamenik et al., 2013; Alexandre et al., 2015). Others study the silicon cycle (e.g., Alexandre et al., 2011; Carey and Fulweiler, 2012, 2016; Song et al., 2012, 2017) and its connections with other biogeochemical cycles (e.g., StreetPerrott and Barker, 2008; Carey and Fulweiler, 2012, 2016; Song et al., 2012, 2017; Alexandre et al., 2015; Cornelis and Delvaux, 2016). Plant silicon and phytoliths are also often used in geoarchaeology to infer past human life (e.g., Tsartsidou et al., 2008; Lancelotti et al., 2014; Hart, 2016), as well as in paleontology to reconstruct ancient vegetation and ecosystems (e.g., Strömberg et al., 2007; Albert and Bamford, 2012) and to trace the evolution of plants and animals (e.g., Prasad et al., 2011; Strömberg, 2011; Katz, 2015; Strömberg et al., 2016).

Thus, plant silicon and phytolith research demonstrates the integration of knowledge from both Earth and life sciences. The plant silicon and phytolith research community studies the effects of plant silicon uptake on other organisms, ecosystems and biogeochemical cycles in tandem with the effects of other organisms, ecosystems and biogeochemical cycles on plant silicon uptake. Likewise, members of the community use geoarchaeological and palaeontological methods to understand the evolution and history of plants and animals, while using knowledge of the evolution of plants and animals to understand changes in the geosphere and Earth themselves. While all these themes are intimately connected, share many theoretical and methodological aspects, and constitute a single 
research topic, only rarely do we see a researcher or a research group that covers a considerable portion of this wide range. One possible reason for this is that the question one asks, the methods one employs to answer them, and the interpretations of these results are strongly influenced by one's parent discipline. Many of us study plant silicon and phytoliths as part or in addition to other themes within our parent disciplines, thus hindering the formation of a common meeting ground or language for plant silicon and phytolith researchers from various parent disciplines. The compilation of the International Code for Phytolith Nomenclature (Madella et al., 2005) is an advancement toward solving part of this problem, albeit somewhat limited to more technical rather than theoretical issues.

By remaining bound to parent disciplines, we sentence our field to remain adjacent to the mainstream (rather than within it) and led by parent disciplines and their agendas. Instead, we should form a greater integrated framework that links our parent disciplines, extends their scopes, increases dialogue among them, and achieves high-order knowledge transfers among them (Figure 1). This is possible now more than ever. Since Earth and life sciences are merging, our field that sits between them can gain a rightful place at the center stage of a new emerging superdiscipline.

\section{SILICON AND PHYTOLITH RESEARCH WITHIN THE INTERDISCIPLINARY EARTH-LIFE SCIENCES MERGER}

As science progresses, so do models of knowledge transfer (Krishnan, 2009). The simplest model is cross-disciplinary knowledge transfer (Figure 1A), in which knowledge from one discipline is borrowed by researchers from another discipline, without true collaboration or dialogue among disciplines. This model is very uncommon because of its inherent shortcoming: that people outside a discipline use knowledge although they have lesser understanding of its underlying assumptions and theories or of specific methodologies (Keene, 1983; Krishnan, 2009). The use of this model nowadays is limited strictly to methodological technicalities.

A second, common model is of multidisciplinary collaboration (Figure 1B), in which one discipline initiates a research programme, on which research teams from other disciplines work independently. The initiating discipline is responsible for synthesis and gains most of the knowledge, while the other disciplines gain less knowledge (often methodological knowledge only). Examples for multidisciplinary collaborations in plant silicon and phytolith research include the use of phytolith analysis to increase botanical knowledge in archaeology (e.g., Albert et al., 1999; Tsartsidou et al., 2008; Lancelotti et al., 2014; Hart, 2016) and palaeoecology (e.g., Albert and Bamford, 2012). Others revealed parts of evolutionary history through new insights into plant physiology and ecology (e.g., Strömberg et al., 2007; Prasad et al., 2011; Strömberg, 2011; Katz, 2015, 2018a). Vice versa, some scholars use plant silicon and phytoliths to identify possible external evolutionary stimuli that may provide insight into the function of plant silicon

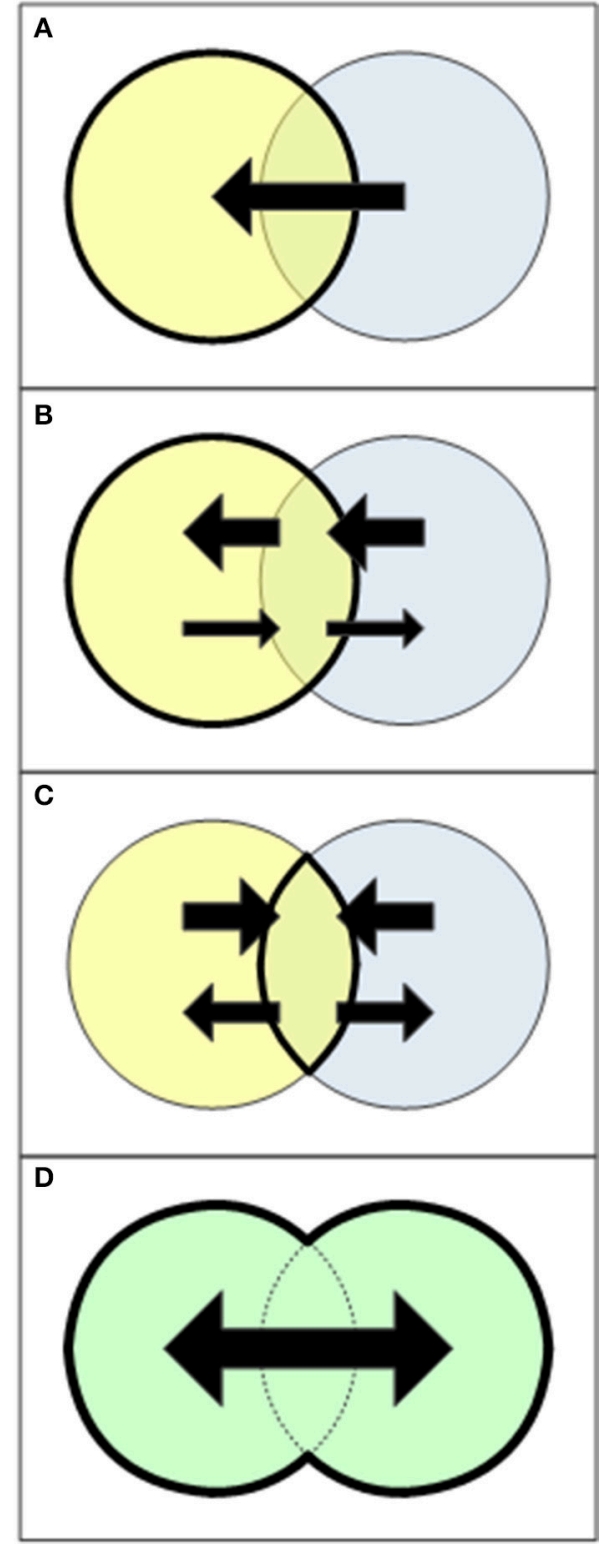

FIGURE 1 | Four models for transfer and sharing among disciplines (Klink et al., 2002; Krishnan, 2009). (A) Cross-disciplinary knowledge transfer: Scholars from one discipline (yellow) use knowledge or methods from another discipline asymmetrically and unidirectionally. (B) Multidisciplinary collaboration: One discipline (yellow) initiates a research programme, on which other disciplines work independently. Synthesis is carried out almost solely by the initiating discipline, and although knowledge transfer is not unidirectional, it is asymmetrical. (C) Interdisciplinary framework: Several disciplines share a theoretical framework. All disciplines contribute knowledge to the shared framework and take part in synthesis. Knowledge flows symmetrically, but through a mediating intersection. (D) A superdiscipline: Disciplines are rearranged by relaxing boundaries among them and thus looking at the union rather than at the intersection. Each discipline bears an equal weight and knowledge flows in all directions (ideally) free of constrains.

and phytoliths (e.g., Katz, 2014, 2015; Strömberg et al., 2016). Finally, phytolith chemistry contributes to our understanding of silicon dissolution in soil and transport in ecosystems (Fraysse 
et al., 2009; Alexandre et al., 2015; Cornelis and Delvaux, 2016).

A third, more complex model is the interdisciplinary framework (Figure 1C), in which researchers from various disciplines contribute and gain relatively equally, but all knowledge transfer is carried out through a shared theoretical framework. Two interdisciplinary frameworks that are of special interest for plant silicon and phytolith researchers are Earth System Science (ESS) and plant functional diversity. ESS is an interdisciplinary framework that attempts "to obtain a scientific understanding of the entire Earth System on a global scale by describing how its component parts and their interactions have evolved, how they function, and how they may be expected to continue to evolve on all time scales" (Earth System Science Committee, 1986) by applying methods and concepts from systems and complexity theories. ESS is therefore a merger of Earth and life sciences that uses systems and complexity theories as the common ground. Both paleontology and ecosystem ecology can be seen as subdivision of ESS, the former focusing on evidence for the evolution of the entire Earth System and the latter focusing on the direct interactions of Earth and life components within ecosystems, hence relying on emergence theory and ecosystem theory (respectively) as subsets of systems and complexity theories. Some studies of the silicon cycle and its interactions with the carbon cycle have quite explicitly used systems and complexity theories (Alexandre et al., 2011; Carey and Fulweiler, 2012, 2016; Cornelis and Delvaux, 2016), and thus represent an integration of plant silicon and phytolith research within the ESS framework.

Plant functional traits are quantitative traits whose values are affected by environmental variables and affect plant, community and ecosystem properties and functioning (Garnier et al., 2016). When discussing ecosystem functions like elemental cycling, plant functional diversity is an interdisciplinary framework that connects Earth and life sciences, with plant functional traits as the common ground that mediates the effects of Earth components on plants and the effects of plants on the ecosystem, again greatly relying on systems theory. Therefore, ESS studies and models can improve if they take into account plant functional traits and types (Beerling, 2007; Van Bodegom et al., 2012; Wullschleger et al., 2014). Although often ignored by mainstream plant functional diversity literature, plant silicon and phytolith contents are gaining increasing recognition as a plant functional trait, and are now known to be involved in plant responses to their environment and plant effects on the environment (Cooke and Leishman, 2011; Carey and Fulweiler, 2012; Song et al., 2012, 2017; Katz, 2014, 2015, 2018b; Schoelynck et al., 2014; Cooke et al., 2016; Schoelynck and Struyf, 2016). Therefore, plant silicon and phytolith research is a part of the interdisciplinary ESS framework.

\section{AN EARTH-LIFE SUPERDISCIPLINE-A PROMISING FUTURE}

These three aforementioned models, and especially multidisciplinary collaborations and interdisciplinary frameworks, have served scientists very well, including in merging knowledge from Earth and life sciences and in plant silicon and phytolith research. However, they are not without shortcomings, including the asymmetry of knowledge transfer, the adherence to certain framing theories, and the limited integration that stems from maintaining boundaries among disciplines.

These shortcomings are overcome in the most advanced model of knowledge transfer and sharing among disciplines, the superdiscipline (Figure 1D), in which boundaries among disciplines are relaxed and knowledge flows freely within the greater domain of the superdiscipline, unbounded to any discipline or framing theory. Although relaxing disciplinary boundaries without the mediation of framing theories is difficult, it is very promising when attempting to answer big, complex, discipline-transgressing and irreducible questions (Krishnan, 2009). The seeds for a merged Earth-life superdiscipline have been sown many years ago. Ecosystem ecology, ESS and plant functional diversity represent great advancements in this direction, yet as interdisciplinary frameworks they are bound to the intersections of the parent disciplines and to the framing of systems and complexity theories. The road to a true Earth-life superdiscipline lies, at least in part, in removing these boundaries, as Beerling (2007) has nicely demonstrated in his book The Emerald Planet, which introduces a synthesis of plant physiology, paleontology and atmospheric sciences.

Somewhat ironically, the fact that plant silicon and phytolith research is adjacent to the mainstream means that it is less constrained than existing interdisciplinary frameworks, and therefore freer to achieve superdiscilinarity and have a leading role in the formation of an Earth-life superdiscipline. A key reason why plant silicon and phytoliths research can take a leading role in forming the new Earth-life superdiscipline is that this phenomenon inherently and intimately links Earth and life. Silicon is the second most abundant element in the Earth's crust, whose uptake by plants affects biotic (Massey and Hartley, 2006; Epstein, 2009; Cooke and Leishman, 2011, 2016; Strömberg, 2011; Guntzer et al., 2012; Schoelynck et al., 2014; Hartley, 2015; Schoelynck and Struyf, 2016; Frew et al., 2016) and abiotic (Street-Perrott and Barker, 2008; Alexandre et al., 2011; Carey and Fulweiler, 2012, 2016; Song et al., 2012 , 2017) processes at multiple scales. Understanding some of these processes requires and benefits from understanding the variation of plant silicon uptake and accumulation across taxa (Hodson et al., 2005; Katz, 2014, 2015; Strömberg et al., 2016), habitats, ecosystems and biomes (Carey and Fulweiler, 2012; Katz et al., 2013, 2014; Schoelynck et al., 2014; Song et al., 2017) and geologic time (Prasad et al., 2011; Strömberg, 2011; Katz, 2015; Strömberg et al., 2016). The references cited in this paragraph alone (and throughout this manuscript) demonstrate that many of us already carry out studies that cross and relax disciplinary boundaries, either in a single study or in a person's or group's combined research portfolio. It seems that this attribute of our field puts it in a better and more developed and advanced position to intimately merge Earth and life sciences, possibly even compared to some fields of 
research that lay deeper within the mainstream and that are more intensively studied, such as photosynthesis and the carbon cycle.

Hence, embedding superdisciplinary thinking in plant silicon and phytolith research can not only advance our field, but increase its impact in the merger of Earth and life sciences into a single superdiscipline. Working toward this goal is a true new frontier for plant silicon and phytolith research, for Earth-life sciences and for science in general.

\section{REFERENCES}

Albert, R. M., and Bamford, M. K. (2012). Vegetation during UMBI and deposition of Tuff IF at Olduvai Gorge, Tanzania (ca. 1.8 Ma) based on phytoliths and plant remains. J. Hum. Evol. 63, 342-350. doi: 10.1016/j.jhevol.2011.05.010

Albert, R. M., Lavi, O., Estroff, L., Weiner, S., Tsatskin, A., Ronen, A., et al. (1999). Mode of occupation of Tabun Cave, Mt Carmel, Israel during the Mousterian Period: a study of sediments and phytoliths. J. Archaeol. Sci. 26, 1249-1260. doi: 10.1006/jasc.1999.0355

Alexandre, A., Basile-Doelsch, I., Delhaye, T., Borshneck, D., Mzaur, J. C., Reyerson, P., et al. (2015). New highlights of phytolith structure and occluded carbon location: 3-D X-ray microscopy and NanoSIMS results. Biogeosciences 12, 863-873. doi: 10.5194/bg-12-863-2015

Alexandre, A., Bouvet, M., and Abbadie, L. (2011). The role of savannas in the terrestrial Si cycle: a case-study from Lamato, Ivory Coast. Glob. Planet. Change 78, 162-169. doi: 10.1016/j.gloplacha.2011.06.007

Beerling, D. (2007). The Emerald Planet. Oxford: Oxford University Press.

Cabanes, D., and Shahack-Gross, R. (2015). Understanding fossil phytolith preservation: the role of partial dissolution in paleoecology and archaeology. PLoS ONE 10:e0125532. doi: 10.1371/journal.pone.0125532

Carey, J. C., and Fulweiler, R. W. (2012). The terrestrial silicon pump. PLoS ONE 7:e52932. doi: 10.1371/journal.pone.0052932

Carey, J. C., and Fulweiler, R. W. (2016). Human appropriation of biogenic silicon - the increasing role of agriculture. Func. Ecol. 30, 1331-1339. doi: 10.1111/1365-2435.12544

Cooke, J., DeGabriel, J. L., and Hartley, S. E. (2016). The functional ecology of plant silicon: geosciences to genes. Func. Ecol. 30, 1270-1276. doi: 10.1111/1365-2435.12711

Cooke, J., and Leishman, M. R. (2011). Is plant ecology more siliceous than we realise? Trends Plant Sci. 16, 61-68. doi: 10.1016/j.tplants.2010.10.003

Cooke, J., and Leishman, M. R. (2016). Consistent alleviation of abiotic stress with silicon addition: a meta-analysis. Func. Ecol. 30, 1340-1357. doi: 10.1111/1365-2435.12713

Cornelis, J. T., and Delvaux, B. (2016). Soil processes drive the biological silicon feedback loop. Func. Ecol. 30, 1298-1310. doi: 10.1111/1365-2435.12704

Coskun, D., Britto, D. T., Huynh, W. Q., and Kronzucker, H. J. (2016). The role of silicon in higher plants under salinity and drought stress. Front. Plant Sci. 7:1072. doi: $10.3389 /$ fpls.2016.01072

Currie, H. A., and Perry, C. C. (2007). Silica in plants: biological, biochemical and chemical studies. Ann. Bot. 100, 1383-1389. doi: 10.1093/aob/mcm247

Earth System Science Committee (1986). Earth System Science: Overview. Washington, DC: NASA

Epstein, E. (2009). Silicon: its manifold roles in plants. Ann. Appl. Biol. 155, 155-160. doi: 10.1111/j.1744-7348.2009.00343.x

Fauteux, F., Remus-Borel, W., Menzies, J. G., and Belanger, R. R. (2005). Silicon and plant disease resistance against pathogenic fungi. FEMS Microbil. Let. 249, 1-6. doi: 10.1016/j.femsle.2005.06.034

Fraysse, F., Pokrovsky, O. S., Schott, J., and Meunier, J. D. (2009). Surface chemistry and reactivity of plant phytoliths in aqueous solution. Chem. Geol. 258, 197-206. doi: 10.1016/j.chemgeo.2008.10.003

Frew, A., Allsopp, P. G., Gherlenda, A. N., and Johnson, S. N. (2016). Increased root herbivory under elevated atmospheric carbon dioxide concentrations

\section{AUTHOR CONTRIBUTIONS}

The author confirms being the sole contributor of this work and approved it for publication.

\section{FUNDING}

The writing of this manuscript was made possible thanks to the Israel Ministry of Science and Technology's support to the Dead Sea and Arava Science Center.

is reversed by silicon-based plant defences. J. Appl. Ecol. 54, 1310-1319. doi: $10.1111 / 1365-2664.12822$

Garnier, E., Navas, M. L., and Grigulis, K. (2016). Plant Functional Diversity: Organism Traits, Community Structure, and Ecosystem Properties. Oxford, UK: Oxford University Press.

Guntzer, F., Keller, C., and Meunier, J. D. (2012). Benefits of plant silicon for crops: a review. Agron. Sust. Dev. 32, 201-213. doi: 10.1007/s13593-011-0039-8

Hart, T. C. (2016). Issues and directions in phytolith analysis. J. Archaeol. Sci. 68, 24-31. doi: 10.1016/j.jas.2016.03.001

Hartley, S. E. (2015). Round and round in cycles? Silicon-based plant defences and vole population dynamics. Func. Ecol. 29, 151-153. doi: 10.1111/1365-2435.12365

Hodson, M. J., Parker, A. G., Leng, M. J., and Sloane, H. J. (2008). Silicon, oxygen and carbon isotope composition of wheat (Triticum aestivum L.) phytoliths: implications for palaeoecology and archaeology. J. Quat. Sci. 23, 331-339. doi: $10.1002 /$ jqs. 1176

Hodson, M. J., White, P. J., Mead, A., and Broadley, M. R. (2005). Phylogenetic variation in the silicon composition of plants. Ann. Bot. 96, 1027-1046. doi: $10.1093 / \mathrm{aob} / \mathrm{mci} 255$

Jacobs, S., Müller, F., Teuchies, J., Oosterlee, L., Struyf, E., and Meire, P. (2013). The vegetation silica pool in a developing tidal freshwater marsh. Silicon 5, 91-100. doi: $10.1007 /$ s12633-012-9136-9

Kamenik, J., Mizera, J., and Randa, Z. (2013). Chemical composition of plant silica phytoliths. Env. Chem. Lett. 11, 189-195. doi: 10.1007/s10311-012-0396-9

Katz, O. (2014). Beyond grasses: the potential benefits of studying silicon accumulation in non-grass species. Front. Plant Sci. 5:376. doi: $10.3389 /$ fpls. 2014.00376

Katz, O. (2015). Silica phytoliths in angiosperms: phylogeny and early evolutionary history. New Phytol. 208, 642-646. doi: 10.1111/nph.13559

Katz, O. (2018a). Extending the scope of Darwin's 'abominable mystery': integrative approaches to understanding angiosperm origins and species richness. Ann. Bot. 121, 1-8. doi: 10.1093/aob/mcx109

Katz, O. (2018b). Silicon content is a plant functional trait: implications in a changing world. Flora. doi: 10.1016/j.flora.2018.08.007 [Epub ahead of print].

Katz, O., Lev-Yadun, S., and Bar (Kutiel), P. (2013). Plasticity and variability in in the patterns of phytolith formation in Asteraceae species along a large rainfall gradient in Israel. Flora 208, 438-444. doi: 10.1016/j.flora.2013.07.005

Katz, O., Lev-Yadun, S., and Bar (Kutiel), P. (2014). Do phytoliths play an antiherbivory role in southwest Asian Asteraceae species and to what extent? Flora 209, 349-358. doi: 10.1016/j.flora.2014.03.010

Keene, A. S. (1983). "Biology, behavior, and borrowing: a critical examination of optimal foraging theory in archaeology," in Archaeological Hammers and Theories, eds J. A. Moore and A. S. Keene (New York, NY: Academic Press), 137-155.

Klink, H. J., Potschin, M., Tress, B., Tress, G., Volk, M., and Steinhardt, U. (2002). "Landscape and landscape ecology," in Development and Perspectives of Landscape Ecology, eds O. Bastian and U. Steinhardt (Amsterdam: Kluwer), $1-47$.

Krishnan, A. (2009). "Five strategies of practicing interdisciplinarity," in ESRC National Centre of Research Methods, NCRM Working Paper Series 02/09.

Kumar, S., Soukup, M., and Elbaum, R. (2017). Silicification in grasses: variation between different cell types. Front. Plant Sci. 8:438. doi: 10.3389/fpls.2017.00438 
Lancelotti, C., Balbo, A. L., Madella, M., Iriarte, E., Rojo-Guerra, M., Royo, J. I., et al. (2014). The missing crop: investigating the use of grasses at Els Trocs, a Neolithic cave site in the Pyrenees (1564 m asl). J. Archeol. Sci. 42, 456-466. doi: 10.1016/j.jas.2013.11.021

Liang, Y., Sun, W., Zhu, Y. G., and Chrisite, P. (2007). Mechanisms of siliconmediated alleviation of abiotic stresses in higher plants: a review. Environ. Pollut. 147, 422-428. doi: 10.1016/j.envpol.2006.06.008

Ma, J. F., and Yamaji, N. (2015). A cooperative system of silicon transport in plants. Trends Plant Sci. 20, 435-442. doi: 10.1016/j.tplants.2015.04.007

Madella, M., Alexandre, A., and Ball, T. (2005). International code for phytolith nomenclature 1.0. Ann. Bot. 96, 253-260. doi: 10.1093/aob/mci172

Massey, F. P., and Hartley, S. E. (2006). Experimental demonstration of the antiherbivore effects of silica in grasses: impacts on foliage digestibility and vole growth rates. Proc. Roy. Soc. B 273, 2299-2304. doi: 10.1098/rspb.2006.3586

Mitani-Ueno, N., Ogai, H., Yamaji, N., and Ma, J. F. (2014). Physiological and molecular characterization of Si uptake in wild rice species. Phys. Plant. 151, 200-207. doi: 10.1111/ppl.12125

Patwardhan, S. V., Emami, F. S., Berry, R. J., Jones, S. E., Naik, R. R., Deschaume, O., et al. (2012). Chemistry of aqueous silica nanoparticle surfaces and the mechanism of selective peptide adsorption. J. Am. Chem. Soc. 134, 6244-6256. doi: $10.1021 /$ ja211307u

Peleg, Z., Saranga, Y., Fahima, T., Aharnoi, A., and Elbaum, R. (2010). Genetic control over silica deposition in wheat awns. Phys. Plant. 140, 10-20. doi: 10.1111/j.1399-3054.2010.01376.x

Prasad, V., Strömberg, C. A. E., Leache, A. D., Samant, B., Patnaik, R., Tang, L., et al. (2011). Late Cretaceous origin of the rice tribe provides evidence for early diversification in the Poaceae. Nat. Comm. 2:480. doi: 10.1038/ncomms1482

Prychid, C. J., Rudall, P. J., and Gregory, M. (2004). Systematics and biology of silica bodies in monocotyledons. Bot. Rev. 69, 377-440. doi: 10.1663/00068101(2004)069[0377:SABOSB]2.0.CO;2

Schoelynck, J., Müller, F., Vandevenne, F., Bal, K., Barão, A. L., Smis, A., et al. (2014). Silicon-vegetation interaction in multiple ecosystems: a review. J. Veg. Sci. 25, 301-313. doi: 10.1111/jvs. 12055

Schoelynck, J., and Struyf, E. (2016). Silicon in aquatic vegetation. Func. Ecol. 30, 1323-1330. doi: 10.1111/1365-2435.12614

Song, Z., Liu, H., Strömberg, C. A. E., Yang, X., and Zhang, X. (2017). Phytolith carbon sequestration in global terrestrial biomes. Sci. Tot. Env. 603, 502-509. doi: 10.1016/j.scitotenv.2017.06.107

Song, Z., Wang, H., Strong, P. J., Li, Z., and Jiang, P. (2012). Plant impact on the coupled biogeochemical cycles of silicon and carbon: implications for biogeochemical carbon sequestration. Earth Sci. Rev. 115, 319-331. doi: 10.1016/j.earscirev.2012.09.006

Street-Perrott, F. A., and Barker, P. A. (2008). Biogenic silica: a neglected component of the coupled global continental biogeochemical cycles of carbon and silicon. Earth Surf. Process. Landforms 33, 1436-1457. doi: $10.1002 /$ esp. 1712

Strömberg, C. A. E. (2011). Evolution of grasses and grassland ecosystems. Annu. Rev. Earth Planet. Sci. 39, 517-544. doi: 10.1146/annurev-earth-040809-152402

Strömberg, C. A. E., Di Stilio, V. S., and Song, Z. (2016). Functions of phytoliths in vascular plants: an evolutionary perspective. Func. Ecol. 30, 1286-1297. doi: 10.1111/1365-2435.12692

Strömberg, C. A. E., Werdelin, L., Friis, E. M., and Sara,ç, G. (2007). The spread of grass-dominated habitats in Turkey and surrounding areas during the Cenozoic: phytolith evidence. Palaeogeog. Palaeoclimatol. Palaeoecol. 250, 18-49. doi: 10.1016/j.palaeo.2007.02.012

Tsartsidou, G., Lev-Yadun, S., Efstratiou, N., and Weiner, S. (2008). Ethnoarchaeological study of phytolith assemblages from an agropastoral village in Northern Greece (Sarakini): development and application of a phytolith difference index. J. Archaeol. Sci. 35, 600-613. doi: 10.1016/j.jas.2007.05.008

Van Bodegom, P. M., Douma, J. C., Witte, J. P. M., Ordo-ez, J. C., Bartholomeus, R. P., and Aerts, R. (2012). Going beyond limitations of plant functional types when predicting global ecosystem-atmosphere fluxes: exploring the merits of traits-based approaches. Glob. Ecol. Biogeog. 21, 625-636. doi: 10.1111/j.1466-8238.2011.00717.x

Wullschleger, S. D., Epstein, H. E., Box, E. O., Euskirchen, E. S., Goswami, S., Iversen, C. M., et al. (2014). Plant functional types in Earth system models: past experiences and future directions for application of dynamic vegetation models in high-latitude ecosystems. Ann. Bot. 114, 1-6. doi: 10.1093/aob/mcu077

Conflict of Interest Statement: The author declares that the research was conducted in the absence of any commercial or financial relationships that could be construed as a potential conflict of interest.

Copyright (c) $2018 \mathrm{Katz}$. This is an open-access article distributed under the terms of the Creative Commons Attribution License (CC BY). The use, distribution or reproduction in other forums is permitted, provided the original author $(s)$ and the copyright owner(s) are credited and that the original publication in this journal is cited, in accordance with accepted academic practice. No use, distribution or reproduction is permitted which does not comply with these terms. 